\title{
Influence of Surface Treatment and Annealing Temperature on the Recombination Processes of the Quantum Dots Solar Cells
}

\author{
Tung Ha Thanh, ${ }^{1,2}$ Vinh Lam Quang, ${ }^{3}$ and Huynh Thanh Dat ${ }^{4}$ \\ ${ }^{1}$ Department for Management of Science and Technology Development, Ton Duc Thang University, Ho Chi Minh City, Vietnam \\ ${ }^{2}$ Faculty of Applied Sciences, Ton Duc Thang University, Ho Chi Minh City, Vietnam \\ ${ }^{3}$ University of Science, Vietnam National University, Ho Chi Minh City, Vietnam \\ ${ }^{4}$ Vietnam National University, Ho Chi Minh City, Vietnam
}

Correspondence should be addressed to Tung Ha Thanh; hathanhtung@tdt.edu.vn

Received 12 June 2016; Revised 31 August 2016; Accepted 4 September 2016

Academic Editor: Taeseup Song

Copyright (C) 2016 Tung Ha Thanh et al. This is an open access article distributed under the Creative Commons Attribution License, which permits unrestricted use, distribution, and reproduction in any medium, provided the original work is properly cited.

We have studied the effect of the surface treatment of the CdS/CdSe quantum dots (QDs) by passivation ZnS layers and annealing temperature on the recombination resistance of the quantum dots solar cells (QDSSCs) based on $\mathrm{TiO}{ }_{2} / \mathrm{CdS} / \mathrm{CdSe} / \mathrm{ZnS}$ photoanodes. The recombination resistance at $\mathrm{TiO}_{2} / \mathrm{QDs}$ contact and in $\mathrm{TiO}_{2}$ film decreased when the QDs were added to the passivation $\mathrm{ZnS}$ layers. Furthermore, we used the $\mathrm{F}^{-}$ions linker and found the best annealing temperature conditions to reduce the recombination resistance of the QDSSCs. As a result, the current density increased from $7.85 \mathrm{~mA} / \mathrm{cm}^{2}$ to $14 \mathrm{~mA} / \mathrm{cm}^{2}$.

\section{Introduction}

Recently, the scientists in the world have been interested in the QDSSCs based on the $\mathrm{TiO}_{2}$ substrate. The QDSSCs based on the QDs have more advantages than the dye sensitized solar cells (DSSCs) based on the molecules for some reasons: (1) the molecules only absorb the light in visible region (2) and are unstable in the air environment. Beside the disadvantages of the molecules, the QDs have some advantages such as quantum confinement effect, the higher coefficients than the dyes, and the generation of multiple electron-hole pairs by a single incident photon $[1,2]$. Moreover, the tunable adsorption band of the QDs can be performed by changing their size for the light harvesters in QDSSCs [3].

For those reasons, the QDSSCs were promised to become the candidate for the high efficiency. Firstly, Vogel and colleagues prepared the QDSSCs based on CdS QDs and obtained the low efficiency [4]. In 2008, many scientists only studied the single QDs as CdS, CdSe, PbS, and so on for the application in the QDSSCs. Therefore, the results obtained the low efficiency. For the next years, the series articles focus on improving efficiency of the QDSSCs with the subject to improve the adsorption of the photoanodes $[5,6]$; to use the different methods such as chemical bath deposition (CBD), successive ionic layer adsorption, and reaction (SILAR) [7]; and to apply the core-shell QDs to reduce the surface states in the QDs [8]. However, the efficiency of the QDSSCs was still lower than the efficiency of the DSSCs at the present due to the high surface states at the $\mathrm{TiO}_{2} / \mathrm{QDs}$ contact and the large diffusion resistance in the $\mathrm{TiO}_{2}$ film.

In this article, we studied the influence of the surface treatment processes by the passivation $\mathrm{ZnS}$ coating and the annealing temperature on the recombination resistance of the QDSSCs based on the $\mathrm{TiO}_{2} / \mathrm{CdS} / \mathrm{CdSe} / \mathrm{ZnS}$ photoanodes.

\section{Experiments}

2.1. CdSe QDs Synthesis. The CdSe QDs were prepared using colloidal synthesis as detailed by previous work [9].

2.2. Growth of $\mathrm{TiO}_{2} / \mathrm{CdS} / \mathrm{CdSe} / \mathrm{ZnS}$ Photoanodes. FTO (Figure 1) was coated with $\mathrm{TiO}_{2}$ films by doctor blade method and annealed at $500^{\circ} \mathrm{C}$ for 45 minutes. Next, the film was immersed in $40 \mathrm{mmol} \mathrm{TiCl}_{4}$ solution for 30 minutes at $70^{\circ} \mathrm{C}$ and sintered at $300^{\circ} \mathrm{C}$ for 15 minutes, $400^{\circ} \mathrm{C}$ for 15 minutes, $450^{\circ} \mathrm{C}$ for 15 minutes, and $500^{\circ} \mathrm{C}$ for 30 minutes to avoid the breaking films. 


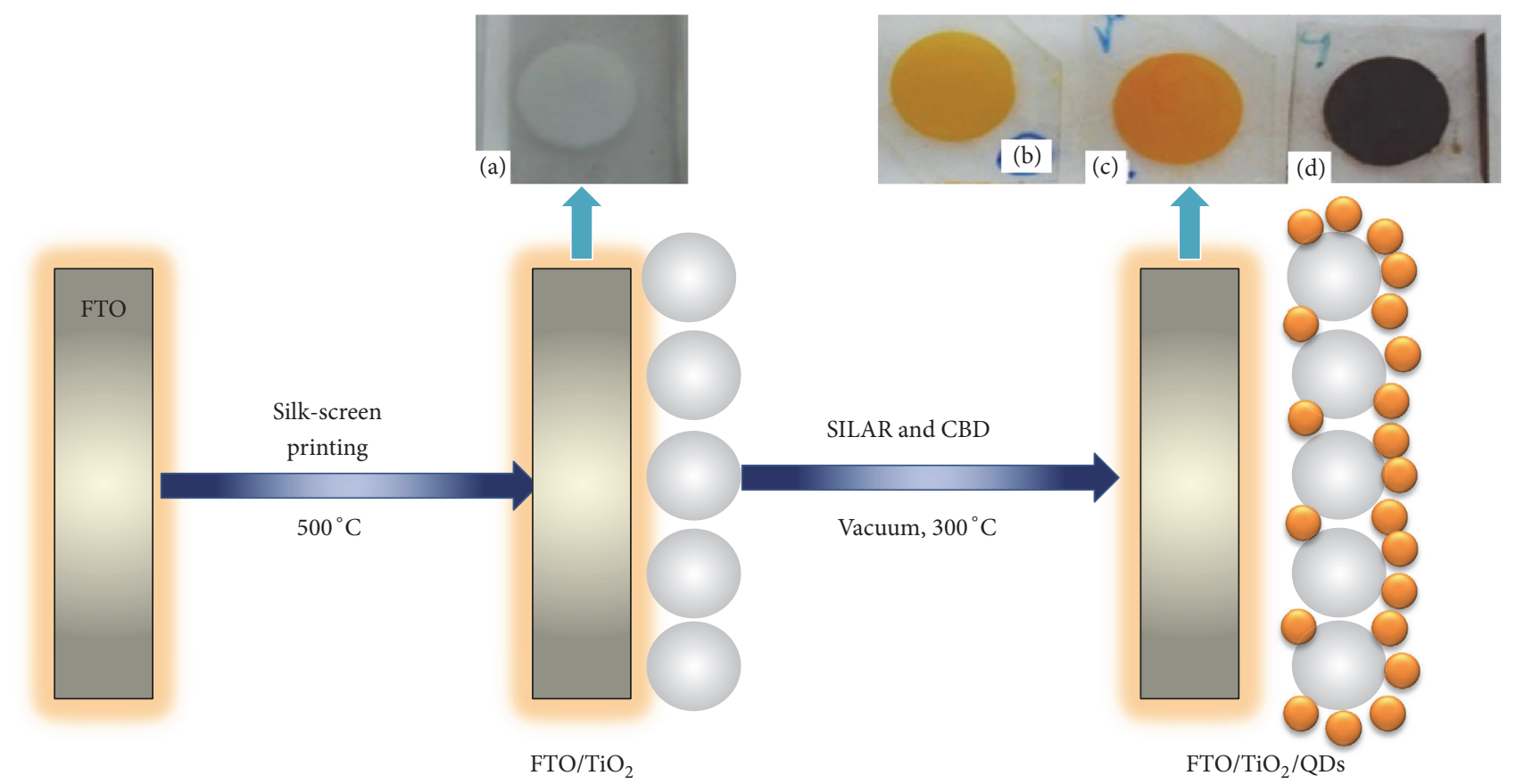

FIGURE 1: Schematic of the structural photoanode.

Firstly, the $\mathrm{FTO} / \mathrm{TiO}_{2}$ films were immersed into $0.5 \mathrm{M}$ $\mathrm{Cd}^{2+}$-ethanol solutions and $0.5 \mathrm{M} \mathrm{S}^{-}$-methanol for 1 minute. After, film was rinsed with methanol and ethanol before being dried in air (a SILAR cycle). The immersion cycle was repeated three times for CdS layers. Secondly, the $\mathrm{TiO}_{2} / \mathrm{CdS}$ assembly was immersed into the CdSe solution (size $\sim 3-4 \mathrm{~nm}$ ) for 24 hours before being dried at room temperature. Thirdly, the $\mathrm{TiO}_{2} / \mathrm{CdS} / \mathrm{CdSe}$ film was immersed into $0.1 \mathrm{M} \mathrm{Zn}^{2+}$ and $0.1 \mathrm{M} \mathrm{S}^{2-}$-solutions for 1 minute and rinsed with pure water (a SILAR cycle). The immersion cycle was repeated two times for ZnS layers. Finally, the $\mathrm{TiO}_{2} / \mathrm{CdS} / \mathrm{CdSe} / \mathrm{ZnS}$ photoanodes were annealed in vacuum at $300^{\circ} \mathrm{C}$ to prevent oxidation.

The coating of $\mathrm{F}^{-}$ions was performed by dipping the $\mathrm{TiO}_{2}$ photoelectrode into a $1 \mathrm{M} \mathrm{NH}_{4} \mathrm{~F}$ aqueous solution for $5 \mathrm{~min}$, rinsed by deionized water $1 \mathrm{~min}$. Two layers of $\mathrm{F}^{-}$ions were coated: the first was coated before the deposition of CdS QDs, the second after the deposition of CdS QDs, and the third after the deposition of CdSe QDs [10].

2.3. Electrolyte Solution. The electrolyte was prepared by the mix of $0.5 \mathrm{M} \mathrm{Na}_{2} \mathrm{~S}, 0.2 \mathrm{M} \mathrm{S}$, and $0.2 \mathrm{M} \mathrm{KCl}$ solutions in Milli$\mathrm{Q}$ ultrapure water/methanol (7:3 by volume) [9].

2.4. Characterization. The morphological samples were investigated using the transmission electron microscopy (TEM). The crystal structure was analyzed using an X-ray diffractometer (XRD) (Philips, PANalytical X'Pert, $\mathrm{CuK}_{\alpha}$ radiation). The absorption properties of the samples were investigated using a diffusive reflectance UV-Vis spectrometer (JASCO V-670). Photocurrent-voltage measurement was from Solarena, Sweden, which has performed on a Keithley 2400 source meter using a simulated AM 1.5 sunlight with an output power of $100 \mathrm{~mW} / \mathrm{cm}^{2}$ produced by a solar simulator. The Electrochemical Impedance Spectroscopy (EIS) was carried out on ZAHNER IM6e Electrochemical Workstations over a frequency range $0.1-10^{5} \mathrm{~Hz}$ at zero bias voltage.

\section{Results and Discussions}

3.1. Morphological and Structure Analysis of the $\mathrm{TiO}_{2} / \mathrm{CdS} /$ CdSe/ZnS Photoanodes. To obtain the particles size, the TEM image of the $\mathrm{TiO}_{2} / \mathrm{CdS} / \mathrm{CdSe} / \mathrm{ZnS}$ photoanode was investigated. Figure 2(a) presents the TEM image of the $\mathrm{TiO}_{2} / \mathrm{CdS} /$ $\mathrm{CdSe} / \mathrm{ZnS}$ photoanode annealed at $300^{\circ} \mathrm{C}$ in vacuum with the $5 \mathrm{~nm}$ size of the QDs. The structure of the photoanodes can be studied by the Raman in Figure 2(b). It indicates that the photoanode has the crystalline structure of Anatase phase with the modes at $144 \mathrm{~cm}^{-1}, 397 \mathrm{~cm}^{-1}, 517 \mathrm{~cm}^{-1}$, and $638.5 \mathrm{~cm}^{-1}$ [11]. Moreover, the Raman also have the $1 \mathrm{LO}$ (long optic) and $2 \mathrm{LO}$ modes of the CdSe QDs at $206,5 \mathrm{~cm}^{-1}$, and $405 \mathrm{~cm}^{-1}$; LO mode of the CdS QDs at $298 \mathrm{~cm}^{-1}$; and LO mode of the passivation $\mathrm{ZnS}$ layers at $364 \mathrm{~cm}^{-1}$ [12]. These results show that the $\mathrm{CdS}$, CdSe, and $\mathrm{ZnS}$ particles were deposited on the $\mathrm{TiO}_{2}$ film.

Beside the Raman, the structural $\mathrm{TiO}_{2} / \mathrm{CdS} / \mathrm{CdSe} / \mathrm{ZnS}$ photoanodes are also considered by the XRD patterns. Figure 2(c) indicates that the $\mathrm{TiO}_{2}$ films have the crystalline structure of the Anatase phase (JCPDS 21-1272) with the strong peak at $25,4^{\circ}$ corresponding to the (101) plane. This result indicates that the growth of the $\mathrm{TiO}_{2}$ film follows the crystal axis [13]. In addition, the XRD patterns also showed that the three peaks at $26,4^{\circ}, 44^{\circ}$, and $56,1^{\circ}$ correspond to (111), (220), and (311) planes of the CdS, CdSe, and ZnS cubic (JCPDS 41-1049, JCPDS 65-2891, and JCPDS 05-0566) [14$16]$. 


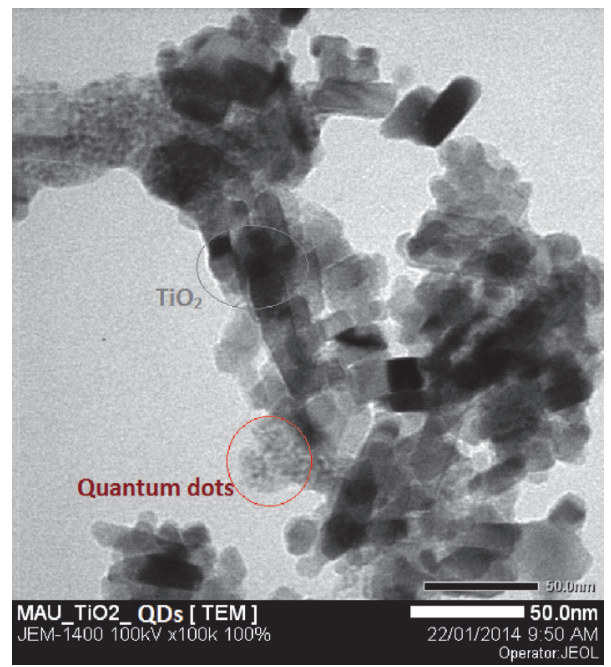

(a)

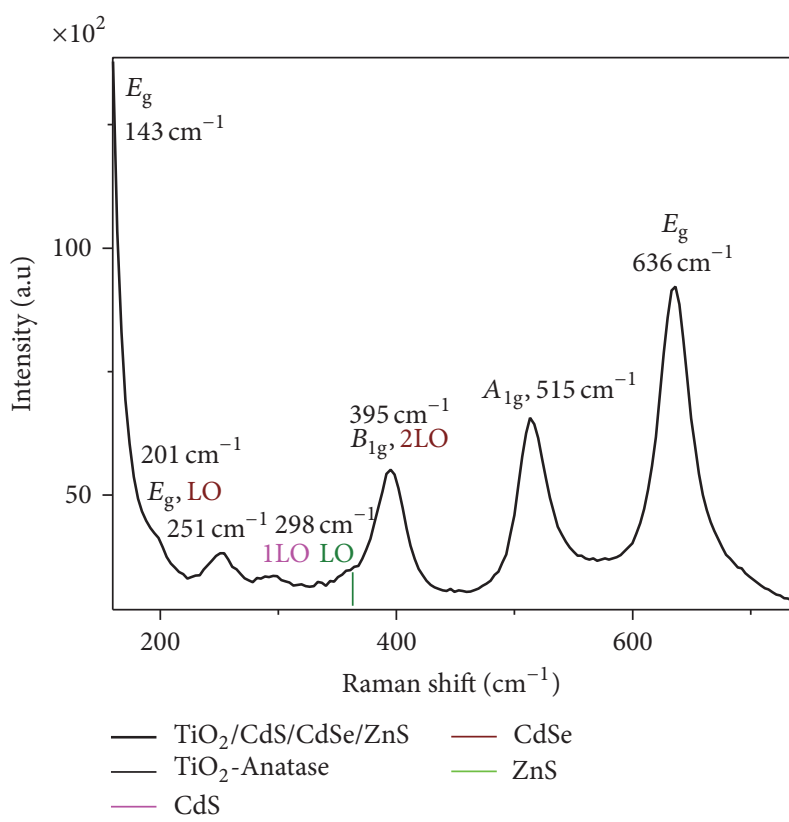

(b)

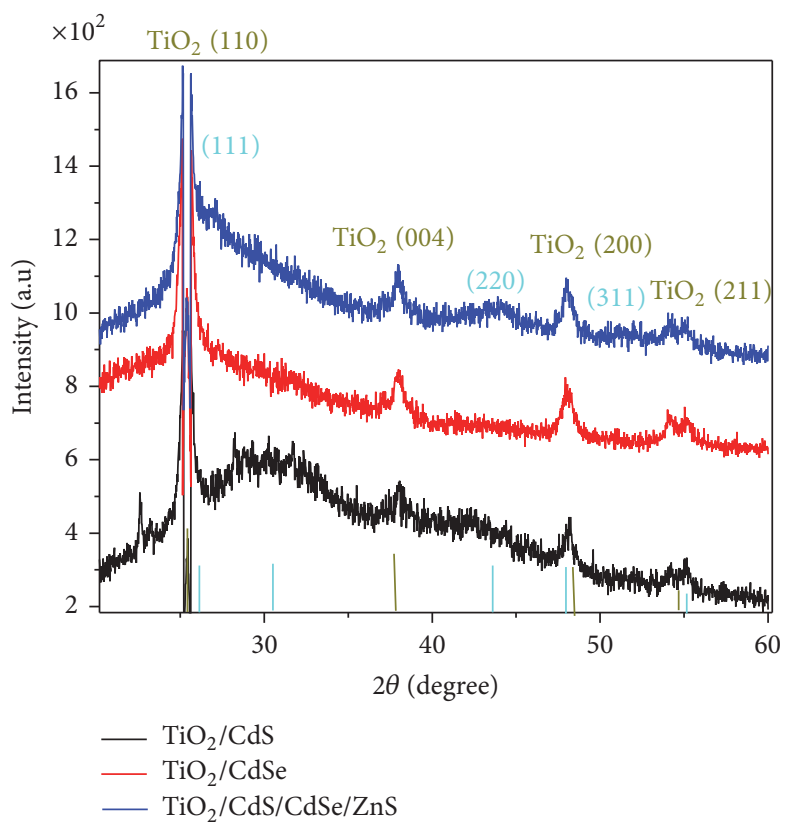

(c)

FIGURE 2: (a) The TEM image, (b) Raman spectra, and (c) XRD patterns of the different photoanodes annealed in vacuum.

3.2. Influence of the Surface Treatment. The combination of the two types QDs can increase the intensity of the absorption of the photoanodes to improve the high performance of the QDSSCs $[5,17,18]$. However, the efficiency of the QDSSCs is still lower than the efficiency of the DSSCs due to the high recombination processes at $\mathrm{TiO}_{2} / \mathrm{QDs}$ contact and the diffusion into the $\mathrm{TiO}_{2}$ film. Therefore, the $\mathrm{ZnS}$ passivation layers were coated on the surface of the CdS/CdSe QDs to reduce the recombination processes and the black electrons into the electrolyte.

Figure 3(a) is the UV-Vis of the different photoanodes to depend on the $\mathrm{ZnS}$ passivation layers. As expected, when thickness of the $\mathrm{ZnS}$ passivation increased, the intensity of the UV-Vis also increased due to the more $\mathrm{ZnS}$ particles loading on the photoanodes [19]. This result is good for the investigation to the influence of the $\mathrm{ZnS}$ passivation thickness on the recombination resistance of the QDSSCs.

To determine the effect of the ZnS thickness on the recombination resistance of the QDSSCs, we considered the $I-V$ curves of the QDSSCs based on the different photoanodes. Figure 3(b) shows the $I-V$ curves of the QDSSCs with or without the ZnS passivation coating (an active area $\left.0.38 \mathrm{~cm}^{2}\right)$ at AM $1.5\left(100 \mathrm{~mW} / \mathrm{cm}^{2}\right)$. In this work, the thickness of the $\mathrm{ZnS}$ layers changed from 0 to 5 layers as shown in Table 1. The QDSSCs based on the $\mathrm{TiO}_{2} / \mathrm{CdS} / \mathrm{CdSe} / \mathrm{ZnS}$ (2 layers) photoanodes have the open voltage $\left(V_{\mathrm{OC}}\right) \sim 0.44 \mathrm{~V}$, the current density $\left(J_{\mathrm{SC}}\right) \sim 14 \mathrm{~mA} / \mathrm{cm}^{2}$, the fill factor $\sim 0.41$, and the efficiency 


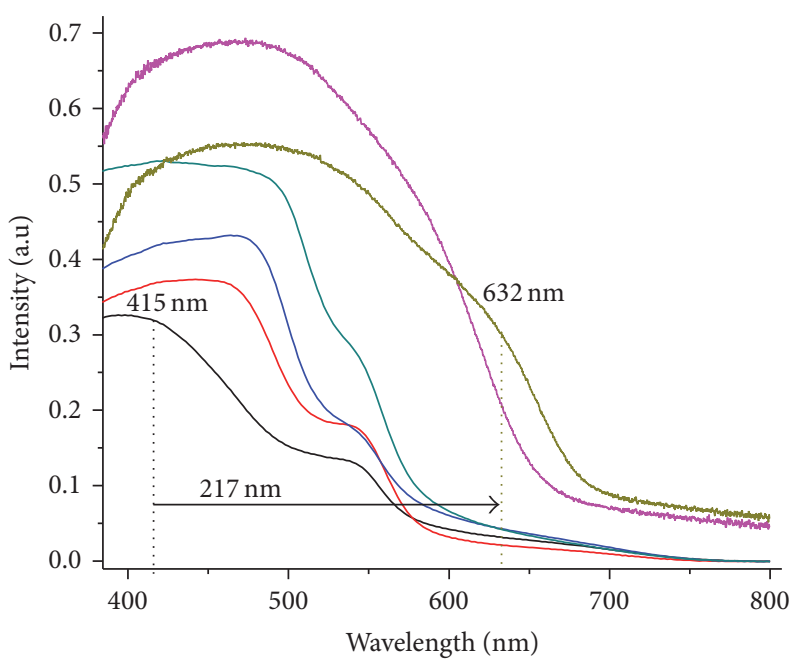

$\begin{array}{ll}-\mathrm{TiO}_{2} / \mathrm{QDs} \text { without } \mathrm{ZnS} & -\mathrm{TiO}_{2} / \mathrm{QDs} / \mathrm{ZnS} \text { (3 layers) } \\ -\mathrm{TiO}_{2} / \mathrm{QDs} / \mathrm{ZnS} \text { (1 layer) } & -\mathrm{TiO}_{2} / \mathrm{QDs} / \mathrm{ZnS} \text { (4 layers) } \\ -\mathrm{TiO}_{2} / \mathrm{QDs} / \mathrm{ZnS} \text { (2 layers) } & -\mathrm{TiO}_{2} / \mathrm{QDs} / \mathrm{ZnS} \text { (5 layers) }\end{array}$

(a)

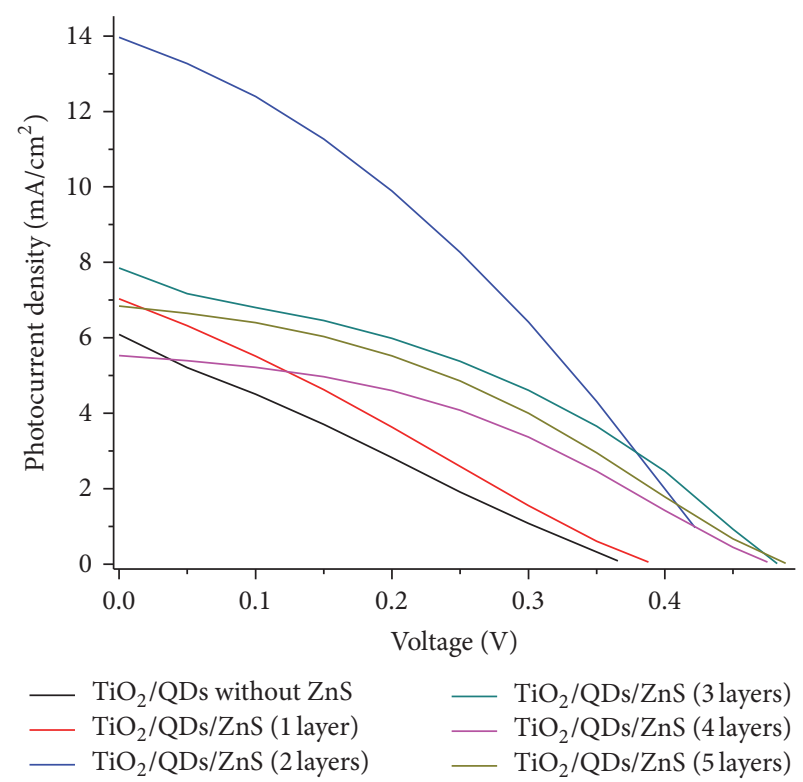

(b)

Figure 3: (a) The UV-Vis spectra and (b) $I$ - $V$ curves of the QDSSCs with the different photoanodes.

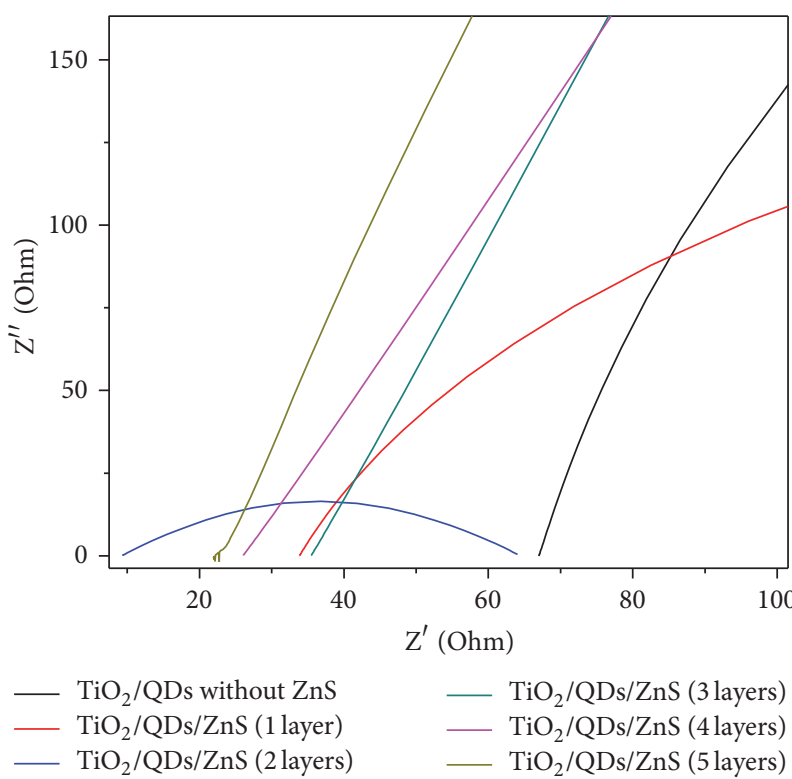

(a)

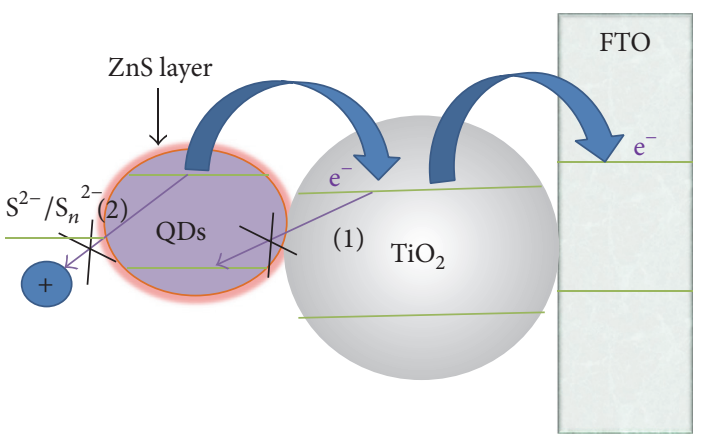

(b)

FIGURE 4: (a) Nyquist plots measured under illuminated conditions for the QDSSCs with the different photoanodes and (b) diagram of the recombination routes for photoelectrons.

$(\boldsymbol{\eta}) \sim 2.1 \%$. This result indicates that the efficiency of the QDSSCs based on the photoanodes with the ZnS passivation coating is higher than the efficiency of the QDSSCs based on the photoanodes without the $\mathrm{ZnS}$ passivation coating. This result agrees well with the UV-Vis spectra. To explain the reasons why the current density increased from $6.04 \mathrm{~mA} / \mathrm{cm}^{2}$ to $14 \mathrm{~mA} / \mathrm{cm}^{2}$, we used the diagram of the recombination routes for photoelectrons in Figure 4(b). The QDSSCs based on the photoanodes without the $\mathrm{ZnS}$ passivation layers can occur in the high recombination processes between the photoelectrons in the conduction band (CB) of the $\mathrm{TiO}_{2}$ with the holes in the valence band (VB) of the CdS/CdSe QDs (process 1) and the holes in the electrolyte (process 2: the back photoelectrons into electrolyte). When the CdS/CdSe QDs were coated with the $\mathrm{ZnS}$ passivation layers, the QDSSCs can be reduced in the recombination processes (1) and (2) in 
TABLE 1: Photovoltaic performance parameters of the QDSSCs.

\begin{tabular}{|c|c|c|c|c|c|}
\hline Number & QDSSCs & $\begin{array}{c}J_{\mathrm{SC}} \\
\left(\mathrm{mA} / \mathrm{cm}^{2}\right)\end{array}$ & $\begin{array}{l}V_{\mathrm{OC}} \\
(\mathrm{V})\end{array}$ & $\begin{array}{c}\text { Fill factor } \\
\text { FF }\end{array}$ & $\begin{array}{c}\text { Efficiency } \\
\eta(\%)\end{array}$ \\
\hline 1 & $\mathrm{TiO}_{2} / \mathrm{CdS} / \mathrm{CdSe}$ without $\mathrm{ZnS}$ & 6.04 & 0.35 & 0.255 & 0.54 \\
\hline 2 & $\mathrm{TiO}_{2} / \mathrm{CdS} / \mathrm{CdSe} / \mathrm{ZnS}$ (1 layer) & 7.03 & 0.39 & 0.26 & 0.72 \\
\hline 3 & $\mathrm{TiO}_{2} / \mathrm{CdS} / \mathrm{CdSe} / \mathrm{ZnS}$ (2 layers) & 14 & 0.44 & 0.33 & 2.1 \\
\hline 4 & $\mathrm{TiO}_{2} / \mathrm{CdS} / \mathrm{CdSe} / \mathrm{ZnS}$ (3 layers) & 7.85 & 0.48 & 0.36 & 1.38 \\
\hline 5 & $\mathrm{TiO}_{2} / \mathrm{CdS} / \mathrm{CdSe} / \mathrm{ZnS}$ (4 layers) & 6.8 & 0.488 & 0.29 & 1.2 \\
\hline 6 & $\mathrm{TiO}_{2} / \mathrm{CdS} / \mathrm{CdSe} / \mathrm{ZnS}$ (5 layers) & 5.53 & 0.475 & 0.27 & 1.0 \\
\hline
\end{tabular}

TABLE 2: The values of parameters were obtained from the EIS measurements.

\begin{tabular}{|c|c|c|c|c|c|c|}
\hline Number & QDSSCs & $\begin{array}{l}R_{\mathrm{S}} \\
(\Omega)\end{array}$ & $\begin{array}{l}R_{\mathrm{ct} 2} \\
(\Omega)\end{array}$ & $\begin{array}{l}R_{\mathrm{ct} 1} \\
(\Omega)\end{array}$ & $\begin{array}{c}\tau \\
(\mathrm{ms}) \\
\end{array}$ & $\begin{array}{c}C_{\mu} \\
(\mu \mathrm{F})\end{array}$ \\
\hline 1 & $\mathrm{TiO}_{2} / \mathrm{CdS} / \mathrm{CdSe}$ without $\mathrm{ZnS}$ & 67 & 1190 & 268 & 4.9 & 104 \\
\hline 2 & $\mathrm{TiO}_{2} / \mathrm{CdS} / \mathrm{CdSe} / \mathrm{ZnS}$ (1 layer) & 33.8 & 333 & 158 & 3.2 & 428 \\
\hline 3 & $\mathrm{TiO}_{2} / \mathrm{CdS} / \mathrm{CdSe} / \mathrm{ZnS}$ (2 layers) & 9.24 & 41.6 & 13.5 & 2.13 & 1040 \\
\hline 4 & $\mathrm{TiO}_{2} / \mathrm{CdS} / \mathrm{CdSe} / \mathrm{ZnS}$ (3 layers) & 35.4 & 1930 & 2330 & 1.6 & 35.4 \\
\hline 5 & $\mathrm{TiO}_{2} / \mathrm{CdS} / \mathrm{CdSe} / \mathrm{ZnS}$ (4 layers) & 22.6 & 976 & 12000 & 1.9 & 28.5 \\
\hline 6 & $\mathrm{TiO}_{2} / \mathrm{CdS} / \mathrm{CdSe} / \mathrm{ZnS}$ (5 layers) & 26 & 59000 & 16100 & 2.2 & 46.4 \\
\hline
\end{tabular}

Figure 4(b) [20]. The results show that the current density and the efficiency of the QDSSCs increased. Moreover, the optimal thickness of the photoanode with the $\mathrm{ZnS}$ layers is 2 layers. The efficiency of the QDSSCs decreased when the thickness of the $\mathrm{ZnS}$ passivation layers increased due to the high recombination processes when the $\mathrm{ZnS}$ particles were more loading on the photoanodes [19].

The EIS using for the QDSSCs was found by Mora-Sero group [21]. The EIS were used for investigation of the transfer processes of photoelectrons through the contacts and diffusion into the $\mathrm{TiO}_{2}$ film such as pumping the photoelectrons from the CdS, CdSe QDs to the $\mathrm{CB}$ of the $\mathrm{TiO}_{2}$; diffusion of the photoelectrons in the $\mathrm{TiO}_{2}$ film; and recombination of the photoelectrons with electrolyte. All processes were described by the circuit diagrams obtained from the Fit and Simulator software of the EIS. After obtaining the EIS, the Nyquist of the circuit diagrams was fitted with the Nyquist of the experiment. At first, we chose the circuit diagrams in the Fit and Simulator software such as resistance, capacitance, and phase element to sign the circuit diagrams. After fitting, we can determine the parameters such as $R_{\mathrm{S}}, R_{\mathrm{ct} 1}, R_{\mathrm{ct} 2}$ in Table 2. The QDSSCs were illuminated by the Simulator with the power $150 \mathrm{~W}$, at $1000 \mathrm{~W} / \mathrm{m}^{2}$.

Figure 4(a) shows the EIS of the QDSSCs based on the $\mathrm{TiO}_{2} / \mathrm{CdS} / \mathrm{CdSe} / \mathrm{ZnS}$ photoanodes with the $\mathrm{ZnS}$ passivation layers changed from 0 to 5 layers. The Nyquist has the three semicircles at the different frequencies. The first semicircle (from left to right in the Figure 4(a)) at the high frequencies $(95 \mathrm{~Hz}-1000 \mathrm{kHz})$ corresponds to the transfer of electrons through the Pt/electrolyte contact and $\mathrm{FTO} / \mathrm{TiO}_{2}$ contact (note $R_{t c 1}$ ). The second semicircle at the middle frequencies $(0.44-95 \mathrm{~Hz})$ shows the resistance against electrons diffusion into the $\mathrm{TiO}_{2}$ films and the resistance against the transfer electrons through the $\mathrm{TiO}_{2} / \mathrm{QD}$ / electrolyte contact (note $\left.R_{c t 2}\right)$. The third semicircle at the low frequencies $(0.049-$ $0.44 \mathrm{~Hz}$ ) is due to the electrons diffusion in $\mathrm{S}_{n}{ }^{2-} / \mathrm{S}^{2-}$.

In Figure 4(a), the radius of semicircles was extended when the thickness of the $\mathrm{ZnS}$ passivation layers increased. In addition, samples 2 and 3 still show the morphology of the three semicircles. However, when the thickness of the $\mathrm{ZnS}$ passivation layers increased, semicircles 1 and 3 were mixed up with semicircles 2 . Therefore, we only discussed the semicircle at the middle frequencies. When the layers of the $\mathrm{ZnS}$ changed from 1 to 2 , the radius of semicircles was narrow ( $R_{c t 2}$ from 1190 to $41.6 \Omega$ ) due to the increased concentration of the photoelectrons through the $\mathrm{TiO}_{2}$ film and the $\mathrm{TiO}_{2} /$ QDs/electrolyte contact [19]. However, the radius of the semicircle increased when the layers of the $\mathrm{ZnS}$ were over 3 layers ( $R_{c t 2}$ from 41.6 to $59000 \Omega$ ). These results indicate that the resistance against the electrons diffusion into the $\mathrm{TiO}_{2}$ film increased $[15,19]$.

Besides the recombination resistance, the chemical capacitance correlates with the electrons concentration in the $\mathrm{TiO}_{2} \mathrm{CB}$ were determined from the EIS, $C_{\mu} \infty$ $\exp \left(q V_{\mathrm{F}} / k_{\mathrm{B}} T\right)$, where $q$ is the elementary charge, $k_{\mathrm{B}}$ is Boltzmann constant and $T$ is the Kelvin temperature, $V_{\mathrm{F}}$ is the difference between the quasi-Fermi level at bias and the equilibrium, and $V_{\mathrm{F}}=\left(E_{\mathrm{F} n}-E_{\mathrm{F} 0}\right) / q . C_{\mu}$ is as a function of $V_{\mathrm{F}}$. Therefore, we can determine the electrons concentration in the $\mathrm{TiO}_{2}$ film when QDSSCs were illuminated. In Table 2, the chemical capacitance of the QDSSCs increased corresponding to the increased electrons concentration in the $\mathrm{CB}$ of the $\mathrm{TiO}_{2}$ film when the CdS/CdSe QDs were coated with the $\mathrm{ZnS}$ passivation layers. These results agree well with the $I-V$ curves and the Nyquist of the QDSSCs. With the ZnS passivation layers, we can reduce the recombination processes 1 and 
TABLE 3: Photovoltaic performance parameters of the QDSSCs.

\begin{tabular}{lccccc}
\hline \multirow{2}{*}{ Number } & QDSSCs & $\begin{array}{c}J_{\mathrm{SC}} \\
\left(\mathrm{mA} / \mathrm{cm}^{2}\right)\end{array}$ & $\begin{array}{c}V_{\mathrm{OC}} \\
(\mathrm{V})\end{array}$ & \multicolumn{2}{c}{ Fill factor } \\
FF & 0.38 & 0.3 & \\
\hline 1 & $\mathrm{TiO}_{2} / \mathrm{CdS} / \mathrm{CdSe} / \mathrm{ZnS}$ at $100^{\circ} \mathrm{C}$ & 5.73 & 0.76 & 0.41 & 0.67 \\
2 & $\mathrm{TiO}_{2} / \mathrm{CdS} / \mathrm{CdSe} / \mathrm{ZnS}$ at $200^{\circ} \mathrm{C}$ & 4.78 & 0.44 & 0.33 & 1.5 \\
3 & $\mathrm{TiO}_{2} / \mathrm{CdS} / \mathrm{CdSe} / \mathrm{ZnS}$ at $300^{\circ} \mathrm{C}$ & 14 & 0.456 & 0.32 & 2.1 \\
4 & $\mathrm{TiO}_{2} / \mathrm{CdS} / \mathrm{CdSe} / \mathrm{ZnS}$ at $400^{\circ} \mathrm{C}$ & 3.04 & & 0.44 \\
\hline
\end{tabular}

TABLE 4: The values of parameters were obtained from the EIS measurements.

\begin{tabular}{lccccc}
\hline Number & QDSSCs & $\begin{array}{c}R_{\mathrm{S}} \\
(\Omega)\end{array}$ & $\begin{array}{c}R_{\mathrm{ct} 2} \\
(\Omega)\end{array}$ & $\begin{array}{c}R_{\mathrm{ct} 1} \\
(\Omega)\end{array}$ & $\begin{array}{c}\tau \\
(\mathrm{ms})\end{array}$ \\
\hline 1 & $\mathrm{TiO}_{2} / \mathrm{CdS} / \mathrm{CdSe} / \mathrm{ZnS}$ at $100^{\circ} \mathrm{C}$ & 26.9 & 393 & 268 & 1.59 \\
$(\mu \mathrm{F})$
\end{tabular}

2 in Figure 4(b). The current density increased because the injected electrons into the $\mathrm{CB}$ of the $\mathrm{TiO}_{2}$ increased. These results agree well with Jung and Jie group as the $\mathrm{PbS}$ and $\mathrm{CdS}$ QDs are coated with the ZnS passivation layers for reducing the recombination processes in the QDSSCs [22, 23].

Mora-Sero said that the recombination processes through the surface states of the QDs were enhanced in the QDSSCs [19]. Moreover, the recombination pathways in the QDSSCs also occurred in the CdS center and between the $\mathrm{TiO}_{2}$ electrons and electrolyte [20]. Therefore, the recombination resistance reduced corresponding to the decreased recombination rate between the $\mathrm{TiO}_{2}$ and electrolyte resulting in the enhanced electrons collection efficiency when the $\mathrm{ZnS}$ passivation layers were coated with the CdS/CdSe QDs in our experiments. These obtained results agree well with the results of Zhang et al. [19, 24]. Moreover, the enhanced electrons concentrations in the $\mathrm{TiO}_{2} \mathrm{CB}$ have been determined to the chemical capacitance valued in Table 2. The chemical capacitance increased when the $\mathrm{ZnS}$ layers coated correspond to the enhanced electrons efficiency in the QDSSCs [24].

3.3. Influence of Annealing Temperature. For improving the crystalline structure of the photoanodes, increasing the ability to the absorbers of light and the electrons transfer [20], we studied the QDSSCs based on the photoanodes at the different temperatures. At first, the photoanodes were annealed in the air environment where the CdS/CdSe QDs were oxidized. Therefore, all samples in this article were annealed in the vacuum. To determine the structure of the material after manufacture, we used XRD patterns. Figure 5(a) is XRD patterns of the photoanodes at different annealing temperatures. The structural analysis of the photoanodes at different annealing temperatures is similar to the analysis from Figure 2(a). The results indicate the $\mathrm{TiO}_{2}$ Anatase, $\mathrm{CdS}$, CdSe, and ZnS QDs with cubic. Moreover, when the temperature rose from $100^{\circ} \mathrm{C}$ to $400^{\circ} \mathrm{C}$ the $\mathrm{XRD}$ intensity increasing with the crystallization proved stronger in the crystal. Figure 5(b) shows the UV-Vis of the photoanodes at the different temperatures. At the high temperature, the peak of the UV-Vis shifted toward the long waves corresponding to the increased size. However, at $400^{\circ} \mathrm{C}$, the $\mathrm{CdS}, \mathrm{CdSe}$, and $\mathrm{ZnS}$ concentrations of the photoanodes were burned and made the CdO. Therefore, the intensity of the UV-Vis spectra was decreased.

The parameters of the $I-V$ curves (Figure 5(c)) were obtained in Table 3. The QDSSCs based on the photoanodes annealed at $300^{\circ} \mathrm{C}$ have the highest efficiency. These results agree well with the UV-Vis. When the temperature increased, the photoanodes were the good crystallization (reduced the recombination processes) corresponding to the shifting toward the long waves. The results indicate that the current density increased because of the high electrons concentration in the $\mathrm{TiO}_{2} \mathrm{CB}$. These results agree well with $\mathrm{Yu}$ group when the temperatures changed from $100^{\circ} \mathrm{C}$ to $250^{\circ} \mathrm{C}$ and the efficiency of the QDSSCs increased from $0.46 \%$ to $2.8 \%$ [8].

To confirm these obtained results in our experiments, the EIS were used for investigation of the recombination resistance and chemical capacitance of the QDSSCs. Figure 6 shows Nyquist plots measured under illuminated conditions for the QDSSCs based on the photoanodes at the different temperatures and (b) the image zoom of (a) (inset). The values of parameters were obtained from the EIS measurements from Table 4. The result indicates that the recombination resistance decreased while the chemical capacitance increased at the high temperature (shown in Table 4). We noted that the decreased surface states and the enhanced electrons concentration in the $\mathrm{TiO}_{2} \mathrm{CB}$ were due to the perfected structural crystal at $300^{\circ} \mathrm{C}$. These results agree well with the $I-V$ characteristic.

\section{Conclusions}

We have successfully prepared the QDSSCs based on the $\mathrm{TiO}_{2} / \mathrm{CdS} / \mathrm{CdSe}$ photoanodes with the $\mathrm{ZnS}$ passivation layers 


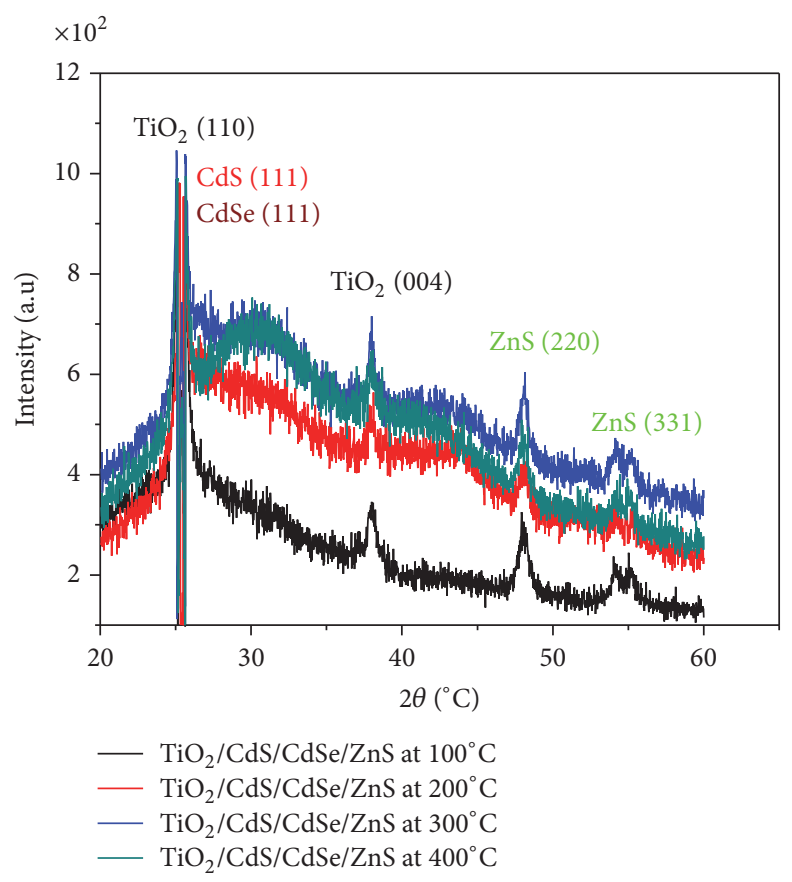

(a)

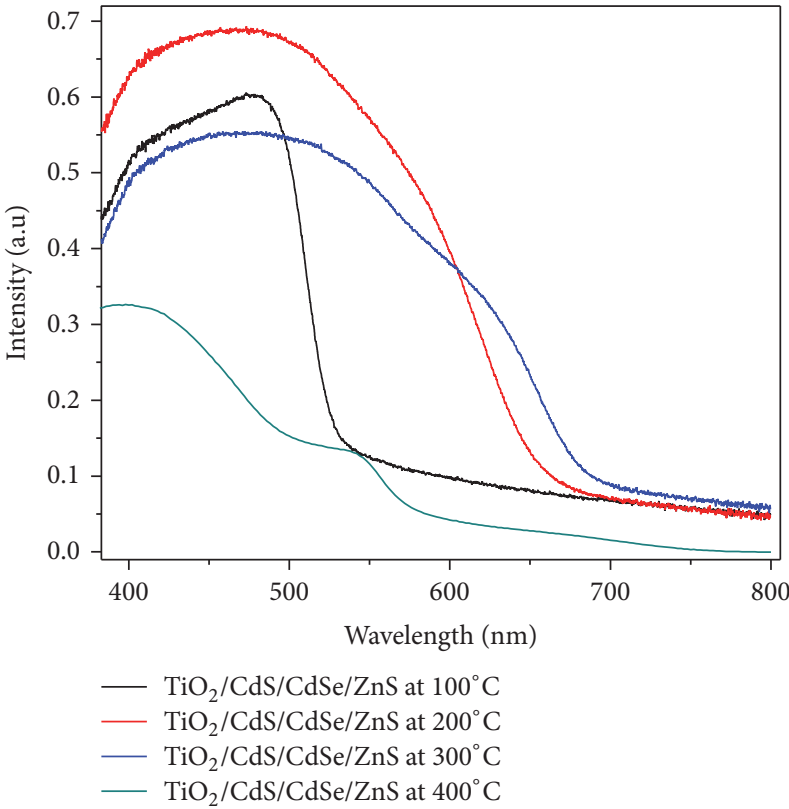

(b)

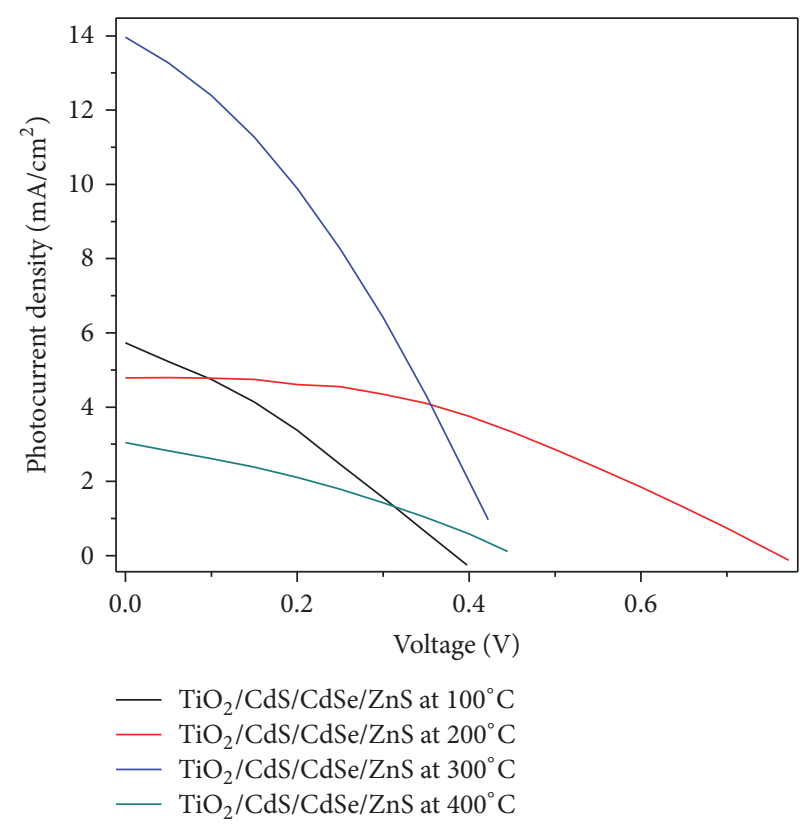

(c)

FIGURE 5: (a) XRD patterns of the photoanodes at the different annealing, (b) the UV-Vis, and (c) $I$ - $V$ curves of the QDSSCs based on the photoanodes at the different temperatures.

and influence of the annealing temperature on the recombination resistance of the QDSSCs. The recombination resistance of the QDSSCs decreased when the photoanodes were coated with the $\mathrm{ZnS}$ passivation layers. In addition, the current density and the electrons concentration in the $\mathrm{TiO}_{2} \mathrm{CB}$ increased due to the increased chemical capacitance. Beside, we also investigated the effect of the annealing temperature on recombination resistance, the chemical capacitance of the
QDSSCs. The result shows that the crystallization structure perfected and reduced the recombination processes in the QDSSCs and the increased electrons concentration into the $\mathrm{TiO}_{2}$ films.

\section{Competing Interests}

The authors have no competing interests to declare. 


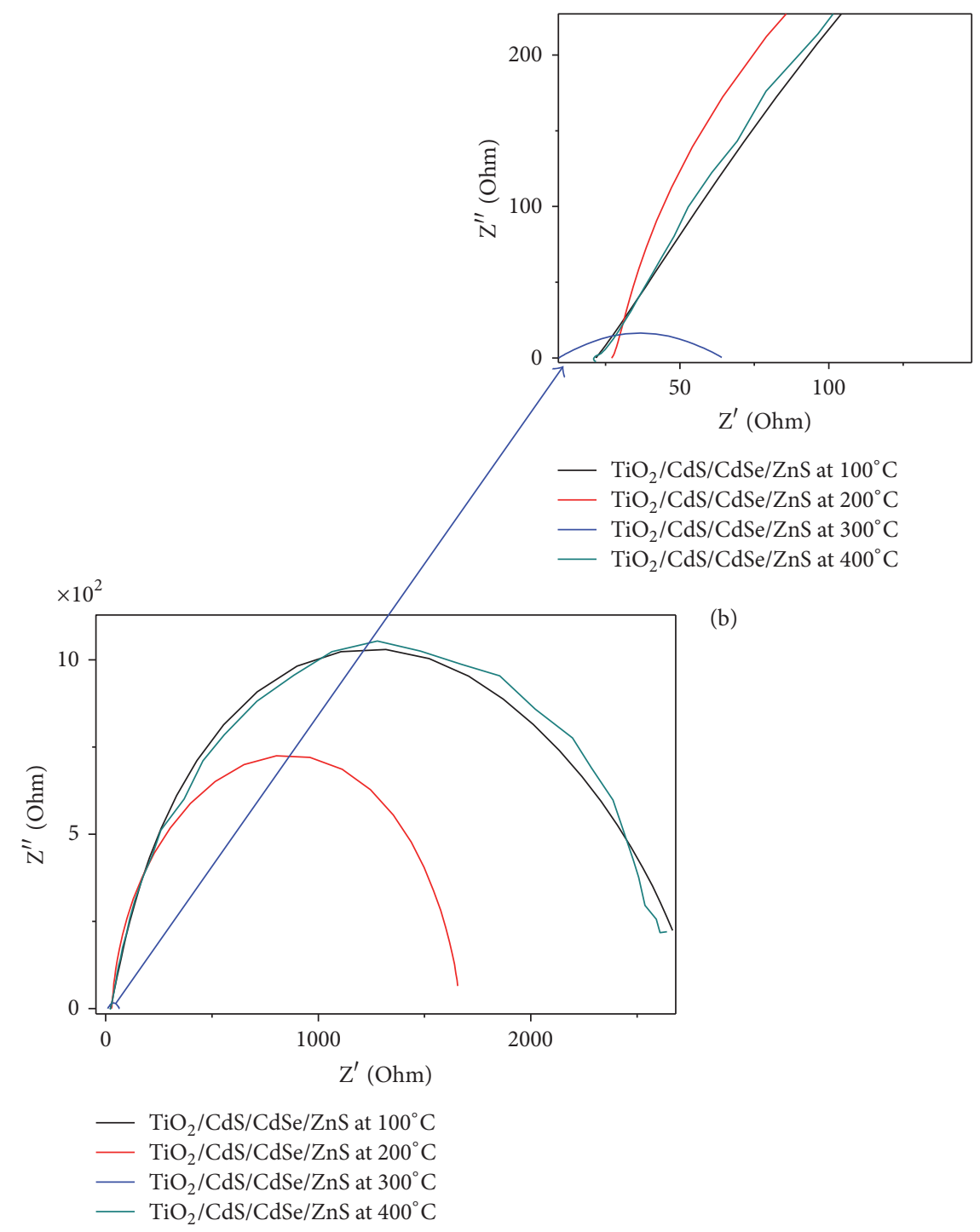

(a)

FIGURE 6: (a) Nyquist plots measured under illuminated conditions for the QDSSCs based on the photoanodes at the different temperatures and (b) small image (inset).

\section{Acknowledgments}

This research is supported by Project CS2015.01.39. The authors would like to thank Ho Chi Minh City of Science, Vietnam. The authors would also like to thank Dr. Dang Vinh Quang for English language editing of the paper.

\section{References}

[1] A. J. Nozik, "Exciton multiplication and relaxation dynamics in quantum dots: applications to ultrahigh-efficiency solar photon conversion," Inorganic Chemistry, vol. 44, no. 20, pp. 6893-6899, 2005.

[2] J. Wu and Z. M. Wang, Quantum Dot Solar Cells, vol. 15, Springer, New York, NY, USA, 2014.

[3] P. Guyot-Sionnest, "Colloidal quantum dots," Comptes Rendus Physique, vol. 9, no. 8, pp. 777-787, 2008.
[4] R. Vogel, K. Pohl, and H. Weller, "Sensitization of highly porous, polycrystalline $\mathrm{TiO}_{2}$ electrodes by quantum sized CdS," Chemical Physics Letters, vol. 174, no. 3-4, pp. 241-246, 1990.

[5] Y.-L. Lee and Y.-S. Lo, "Highly efficient quantum-dot-sensitized solar cell based on co-sensitization of CdS/CdSe," Advanced Functional Materials, vol. 19, no. 4, pp. 604-609, 2009.

[6] Q. Zhang, Y. Zhang, S. Huang et al., "Application of carbon counterelectrode on CdS quantum dot-sensitized solar cells (QDSSCs)," Electrochemistry Communications, vol. 12, no. 2, pp. 327-330, 2010.

[7] J. Chen, D. W. Zhao, J. L. Song et al., "Directly assembled CdSe quantum dots on $\mathrm{TiO}_{2}$ in aqueous solution by adjusting $\mathrm{pH}$ value for quantum dot sensitized solar cells," Electrochemistry Communications, vol. 11, no. 12, pp. 2265-2267, 2009.

[8] X.-Y. Yu, B.-X. Lei, D.-B. Kuang, and C.-Y. Su, "High performance and reduced charge recombination of CdSe/CdS quantum dot-sensitized solar cells," Journal of Materials Chemistry, vol. 22, no. 24, pp.12058-12063, 2012. 
[9] T. Ha Thanh, V. Lam Quang, and D. Huynh Thanh, "Determination of the dynamic resistance of the quantum dots solar cells by one I-V curve and electrochemical impedance spectra," Solar Energy Materials and Solar Cells, vol. 143, pp. 269-274, 2015.

[10] M. Samadpour, P. P. Boix, S. Giménez et al., "Fluorine treatment of $\mathrm{TiO}_{2}$ for enhancing quantum dot sensitized solar cell performance," Journal of Physical Chemistry C, vol. 115, no. 29, pp. 14400-14407, 2011.

[11] A. Tubtimtae and M.-W. Lee, "Effects of passivation treatment on performance of CdS/CdSe quantum-dot co-sensitized solar cells," Thin Solid Films, vol. 526, pp. 225-230, 2012.

[12] J. Y. Kim, S. B. Choi, J. H. Noh et al., "Synthesis of CdSe-TiO nanocomposites and their applications to $\mathrm{TiO}_{2}$ sensitized solar cells," Langmuir, vol. 25, no. 9, pp. 5348-5351, 2009.

[13] G. I. Koleilat, L. Levina, H. Shukla et al., "Efficient, stable infrared photovoltaics based on solution-cast colloidal quantum dots," ACS Nano, vol. 2, no. 5, pp. 833-840, 2008.

[14] M. Kouhnavard, S. Ikeda, N. A. Ludin et al., "A review of semiconductor materials as sensitizers for quantum dot-sensitized solar cells," Renewable and Sustainable Energy Reviews, vol. 37, pp. 397-407, 2014.

[15] J.-H. Ahn, R. S. Mane, V. V. Todkar, and S.-H. Han, "Invasion of CdSe nanoparticles for photosensitization of porous $\mathrm{TiO}_{2}$," International Journal of Electrochemical Science, vol. 2, no. 7, pp. 517-522, 2007.

[16] A. Kongkanand, K. Tvrdy, K. Takechi, M. Kuno, and P. V. Kamat, "Quantum dot solar cells. Tuning photoresponse through size and shape control of $\mathrm{CdSe}-\mathrm{TiO}_{2}$ architecture," Journal of the American Chemical Society, vol. 130, no. 12, pp. 4007-4015, 2008.

[17] P. Sudhagar, J. H. Jung, S. Park et al., "The performance of coupled (CdS:CdSe) quantum dot-sensitized $\mathrm{TiO}_{2}$ nanofibrous solar cells," Electrochemistry Communications, vol. 11, no. 11, pp. 2220-2224, 2009.

[18] Z. Yu, Q. Zhang, D. Qin et al., "Highly efficient quasi-solidstate quantum-dot-sensitized solar cell based on hydrogel electrolytes," Electrochemistry Communications, vol. 12, no. 12, pp. 1776-1779, 2010.

[19] Y. Zhang, J. Zhu, X. Yu, J. Wei, L. Hu, and S. Dai, “The optical and electrochemical properties of CdS/CdSe co-sensitized $\mathrm{TiO}_{2}$ solar cells prepared by successive ionic layer adsorption and reaction processes," Solar Energy, vol. 86, no. 3, pp. 964-971, 2012.

[20] L.-W. Chong, H.-T. Chien, and Y.-L. Lee, "Assembly of CdSe onto mesoporous $\mathrm{TiO}_{2}$ films induced by a self-assembled monolayer for quantum dot-sensitized solar cell applications," Journal of Power Sources, vol. 195, no. 15, pp. 5109-5113, 2010.

[21] I. Mora-Seró, S. Giménez, T. Moehl et al., "Factors determining the photovoltaic performance of a CdSe quantum dot sensitized solar cell: the role of the linker molecule and of the counter electrode," Nanotechnology, vol. 19, no. 42, Article ID 424007, 2008.

[22] S. W. Jung, J.-H. Kim, H. Kim, C.-J. Choi, and K.-S. Ahn, “ZnS overlayer on in situ chemical bath deposited CdS quantum dotassembled $\mathrm{TiO}_{2}$ films for quantum dot-sensitized solar cells," Current Applied Physics, vol. 12, no. 6, pp. 1459-1464, 2012.

[23] J. Jiao, Z.-J. Zhou, W.-H. Zhou, and S.-X. Wu, "CdS and $\mathrm{PbS}$ quantum dots co-sensitized $\mathrm{TiO}_{2}$ nanorod arrays with improved performance for solar cells application," Materials Science in Semiconductor Processing, vol. 16, no. 2, pp. 435-440, 2013.

[24] J. S. Woo, K. Jae-Hong, K. Hyunsoo, C. Chel-Jong, and A. Kwang-Soon, "Enhanced electron lifetime in CdS quantum dot-sensitized solar cells with nanoporous-layer-covered $\mathrm{TiO}_{2}$ nanotube arrays," Current Applied Physics, vol. 12, no. 6, pp. 1459-1464, 2012. 

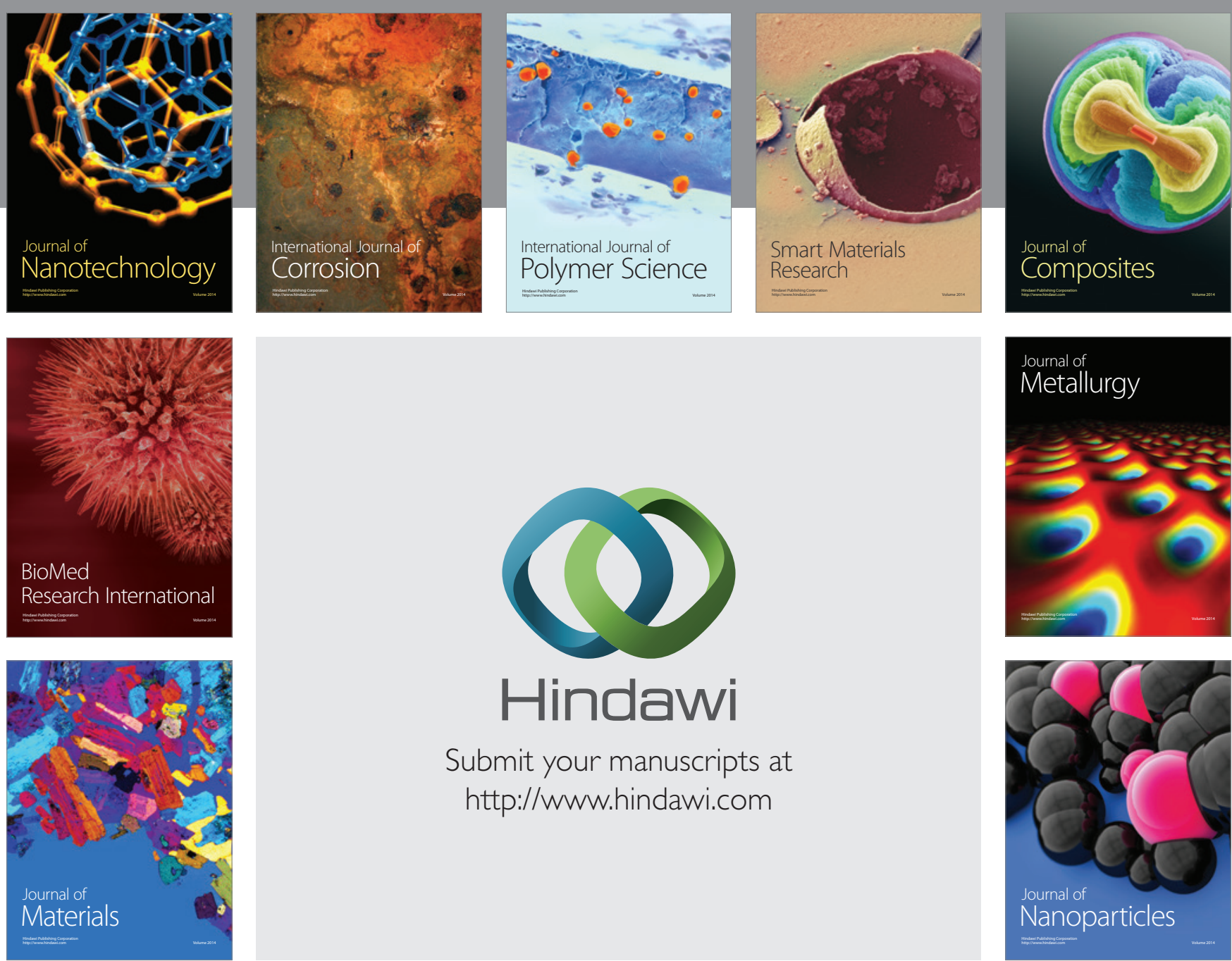

\section{Hindawi}

Submit your manuscripts at

http://www.hindawi.com

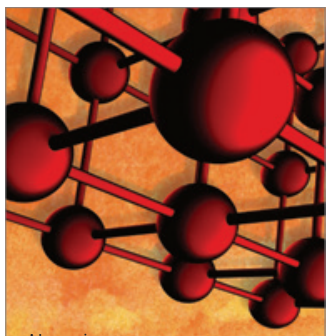

Materials Science and Engineering
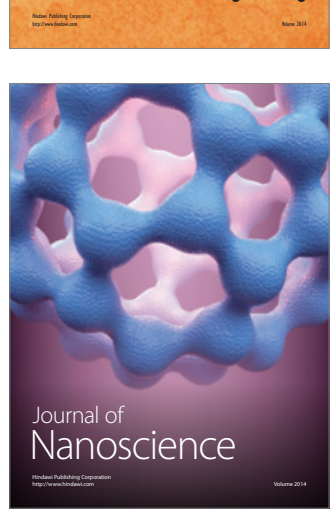
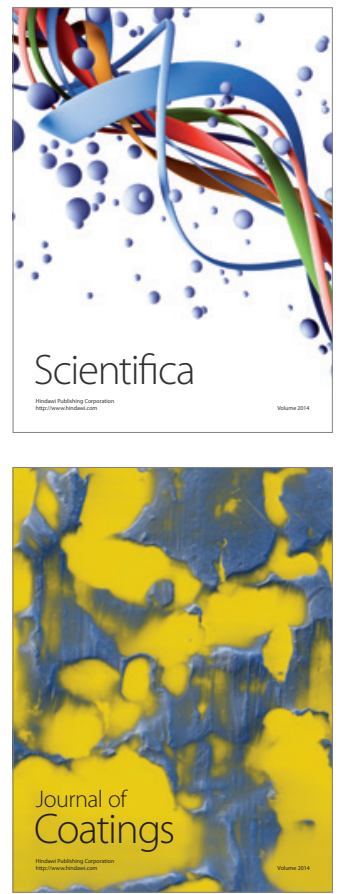
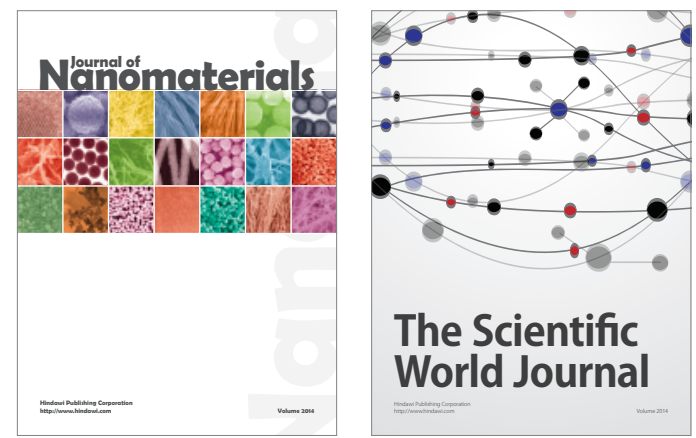

The Scientific World Journal
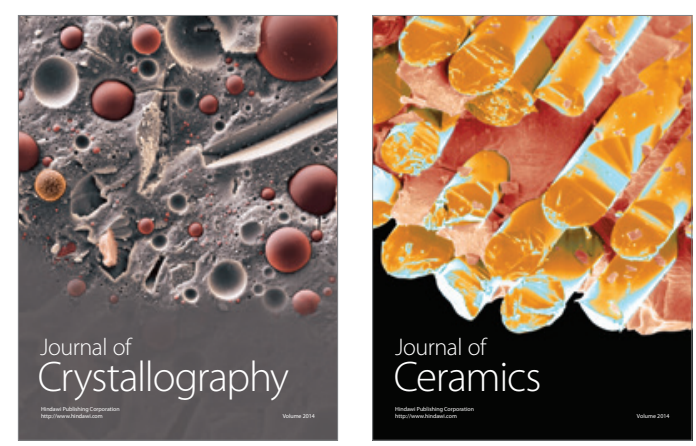
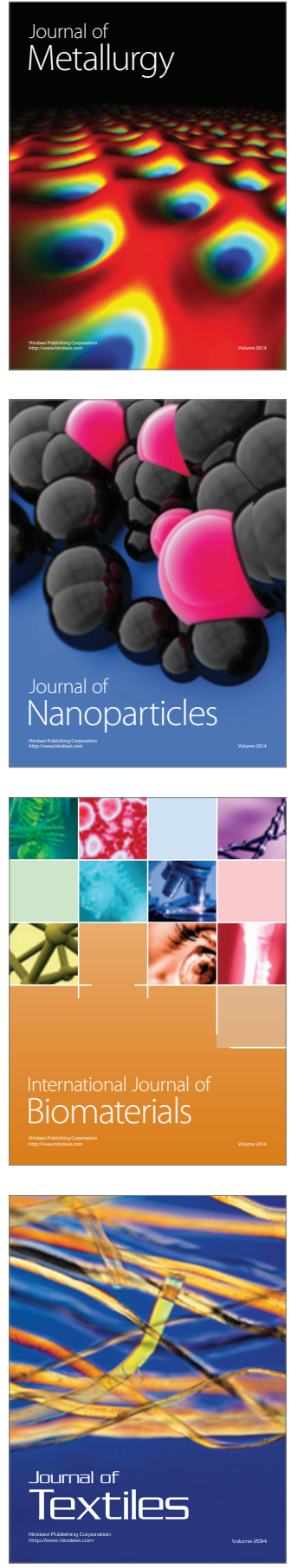